\title{
Effect of three Ca-sources applications on fruit quality attributes of three peach cultivars in Pakistan
}

Muhammad Wahab ${ }^{1 *}$, Zia Ullah², Muhammad Usman ${ }^{3}$, Sadaf Nayab ${ }^{4}$, Murad Ullah ${ }^{1}$, Muhammad Sajid ${ }^{1}$ and Kamran Sohail ${ }^{5}$

1. Department of Horticulture, University of Agriculture, Peshawar, Pakistan

2. Floriculture Section, Agricultural Research Institute Tarnab Farm, Peshawar, Pakistan

3. Department of Entomology, Bacha Khan University, Charsada, Pakistan

4. Department of Plant Breeding and Genetics, University of Agriculture, Peshawar, Pakistan

5. Department of Entomology, University of Agriculture, Peshawar, Pakistan

*Corresponding author's email: Muhammadwahab111@gmail.com

Citation

Muhammad Wahab, Zia Ullah, Muhammad Usman, Sadaf Nayab, Murad Ullah, Muhammad Sajid and Kamran Sohail. Effect of three Ca- sources applications on fruit quality attributes of three peach cultivars in Pakistan. Pure and Applied Biology. Vol. 5, Issue 3, pp464-470. http://dx.doi.org/10.19045/bspab.2016.50060

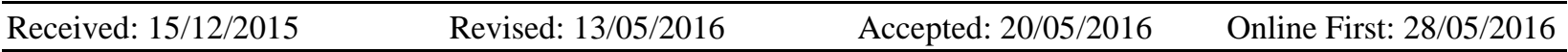

\section{Abstract}

A research to investigate the "effect of three ca- sources applications on fruit quality attributes of three peach cultivars in Pakistan" was carried out at Peach orchard, Horticulture section research farm, The University of Agriculture Peshawar, Pakistan during the spring, 2013. Three Casources (calcium chloride, calcium nitrate, calcium oxide) at $1.5 \%$ were sprayed on Peach cultivars (Early Grand, Florida King, Tex.A.69) and control were untreated plants. The experiment was presented in Randomized Complete Block Design with split plot arrangements having three replications. The Ca-sources kept in main plot and cultivars were kept in sub plot. In the experiment all the studied parameters were significantly affected by Calcium Sources and peach cultivars. Among Ca-sources, the highest Vitamin C Content $\left(7.03 \mathrm{mg} 100 \mathrm{ml}^{-1}\right)$, TSS $\left(6.31{ }^{0}\right.$ Brix $)$, fruit $\mathrm{pH}(3.70)$ and fruit firmness $\left(7.65 \mathrm{Kg} . \mathrm{cm}^{-2}\right)$ with lowest Number of fruits drop (15.33) and percent acidity $(0.60 \%)$ was recorded in fruits that were sprayed with calcium chloride. Among cultivars highest TSS (6.26 ${ }^{0}$ Brix), fruit $\mathrm{pH}$ (3.67) and fruit firmness (6.88 $\mathrm{Kg} . \mathrm{cm}^{-2}$ ) with the lowest number of fruits drop (17.75) was observed in fruits of peach Tex.A.69 cultivar. It is therefore concluded that peach grower should grow peach cultivar Tex.A.69 and calcium chloride should be used as foliar application to improve the quality attributes of peach cultivars.

Key words: Ca-Sources; Peach quality; Peach cultivars

\section{Introduction}

Peach, (Prunus persica L.) belongs to family Rosaceae and is one of the most important stone fruit of the temperate nature. Peach is looked as native to China and was probably developed in Persian. Two peach verities i.e. cling to party and free stone mostly used worldwide. It is one of the important fruit of Pakistan, especially in areas of Peshawar 
and Swat. Early Grand, Florida King, 6-A and 8-A are the most popular cultivars. In Baluchistan primarily shah Pasand, Golden Early, and Shireen are cultivated [1]. In Pakistan peaches are cultivated on an area of 15.2 thousand hectares with the production of 52.6 thousand tons. In Khyber pakhtunkhwa peach is grown on 5.6 thousand hectares area with a complete production of 30.8 thousand tons [2]. Quetta, Kalat. Peshawar and swat valley are the main peach producing areas of Pakistan [1]. Peach is delicious in taste and attractive in aroma. It contains sugar of $10-14 \%$, protein of $2 \%$ and rich in ascorbic acid, vitamins $\mathrm{A}$ and $\mathrm{B}$ except iron, phosphorus and calcium [3]. Peach is classified as of climacteric fruit because of increasing respiration during ripening. The peach fruit is drupe, with epidermis (skin) fuzzy (pubescence) as in normal peach or glabrous (smooth) as in nectarine. Skin and flesh colour may be white or yellow (some cultivars red). The endocarp (stone) is lignified, the outer surface being deeply furrowed and pitted. Peach fruit weight varies, but mostly $228 \mathrm{~g}$ depending upon cultivar [4]. Calcium is a major constituent of cell walls and membranes and plays a role in their proper functioning. It also play important role in pollen germination, cell division, environmental signaling and protecting cells from toxins [5]. Calcium deficiency symptoms to appear are a reduction in root growth [5]. Subsequent roots that develop are often swollen and stubby. Early leaf symptoms of Calcium deficiency includes marginal leaf chlorosis, which develops into necrosis and eventually leads to defoliation. Fruits on $\mathrm{Ca}$ deficient trees are smaller, lower in sugar and have poorer colour and flavor [5]. As $\mathrm{Ca}$ is found in cell walls, it has been associated with cell rigidity and fruit firmness. Addition of $\mathrm{Ca}$ has successfully delayed softening of various fruits [6] and reduced decay [7]. Pre harvest applications of $\mathrm{Ca}$ spray have reduced fruit rot, maintained firmness and improved flavor, aroma and appearance of peaches $[8,9]$. This study aimed to find out the best Ca-Sources as foliar application for agro climatic condition of Peshawar for improving the quality attributes of peach cultivars.

\section{Materials and methods}

To investigate the effect of three ca- sources applications on fruit quality attributes of three peach cultivars in Pakistan was carried out at Peach orchard, Horticulture section research farm, The University of Agriculture Peshawar, Pakistan during the spring, 2013. Following two factors were examined. Factor A, three Ca-sources $\left(\mathrm{CaCl}_{2}\right.$, $\left.\mathrm{Ca}\left(\mathrm{NO}_{3}\right)_{2}, \mathrm{CaO}\right)$ at $1.5 \%$ along with control. Factor B, different peach cultivars (Early Grand, Florida King, Tex. A.69). The study was laid out in Randomized Complete Block Design (RCBD) with split plot arrangement. The experiment comprises of twelve treatments and each treatment was replicated three times. The Ca-Sources $(1.5 \%)$ as pre harvest spray applied at Berry stage of fruit. A total of 72 trees were selected and 2 trees per treatment per replication were selected for foliar application.

\section{Number of fruits drop}

From two randomly selected trees all the dropped fruits were collected in each replication. The numbers of fallen fruits were then counted and their means were recorded.

\section{Fruit firmness $\left({\mathrm{Kg} . \mathrm{cm}^{-2}}^{-2}\right.$}

Fruit firmness were calculated by Penetrometer (hand held with $8 \mathrm{~mm}$ ) plunger.

\section{Total soluble solids ( ${ }^{\mathbf{}} \mathrm{Brix}$ )}

TSS was determined with the help of Refract meter prisms represented in The Association of official Analytical Chemist [26].

\section{Fruit pH}


$\mathrm{pH}$ meter was used to determined the fruits $\mathrm{pH}$ of randomly taken fruits.

\section{Percent acidity}

Acid base titration procedure was used to calculate percent acidity as described in The Association of official Analytical Chemist [26].

\section{Vitamin $C$ content $\left(\mathrm{mg} 100 \mathrm{ml}^{-1}\right)$}

Vitamin C Content was calculated by the Titramitric method (Redox titration) as represented in The Association of official Analytical Chemist [26].

\section{Statistical procedure}

The experiment was laid out in Randomized Complete Block design with split plot arrangement and means were separated using (LSD) test [10].

\section{Results and discussions \\ Number of fruits drop}

Data obtained for number of fruits drop as effected by $\mathrm{Ca}$-sources revealed that maximum number of fruits drops (26.61) was recorded in control treatment followed by number of fruits drops i.e. 20.00 and 18.88 recorded in trees with calcium nitrate and calcium oxide, respectively. Whereas the minimum number of fruits drops (15.33) recorded in plants sprayed with $\mathrm{CaCl}_{2}$. (Table 1)

Data obtained for peach cultivars showed that maximum number of fruits drop (21.65) was observed in Florida King while the minimum number of fruits drops (17.75) was recorded in Tex.A.69. (Table 1)

Calcium chloride helped in flowering, pollination and fertilization [11] and its application helped to improve the cellulose and lignin formation and these materials are required for building plant structure and prevent abscission layer formation hence, pre harvest fruit drop was significantly reduce[12]. The number of fruit drops was more in calcium nitrate and calcium oxide treatment as compare to calcium chloride treatment. The foliar application of $\mathrm{CaCl}_{2}$ significantly increased the fruit set and reduced the pre harvest fruit drop $[13,14]$.

Fruit firmness $\left(\mathrm{Kg}_{\mathbf{g}} \mathrm{cm}^{-2}\right)$

Data obtained for fruit firmness revealed that highest fruit firmness (7.65) in $\mathrm{CaCl}_{2}$ treatment whereas the lowest (5.31) was recorded in control. The fruit firmness recorded in calcium chloride and calcium oxide treatments were 6.71 and 6.29, respectively. (Table 1)

Data obtained for peach cultivars also revealed that more fruit firmness 6.88 $\mathrm{Kg} . \mathrm{cm}^{-2}$ was found in Tex.A.69 cultivar, whereas the minimum fruit firmness 6.14 $\mathrm{Kg} \cdot \mathrm{cm}^{-2}$ was recorded in Early Grand cultivar. (Table 1)

The determination of fruit reduction of peaches is because of classification of fermental degrading in un soluble proto pectin's to more simple tractable pectin, solubilizing contents of cells and wall of cells owing to increase in pectin esterase activity[15]. Sources of Calcium could reduce hardness of fruit as it is an essential part of structure of a cell and it also influences integrity of cell membrane [16]. The source of Calcium can also detain glacto lipid breakdown, increase norm of sterol conjugation and creates effects on the post harvests life of a fruit [17]. The pre harvest-application of the calcium chloride in peaches was effective in improving the fruit firmness [18]. These results are in conformity with the findings of [19-21], they concluded that application of sources of calcium helped in reducing the loss of fruit determination during the storage, and calcium chloride reduce the internal depression which helped in reducing the respiration and fruit determination. 


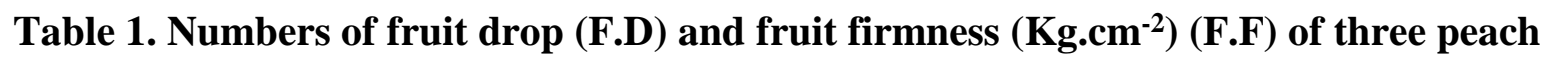
cultivars as affected by the three foliar applications of Ca-Sources at $1.5 \%$

\begin{tabular}{ccccccccccc} 
& \multicolumn{2}{c}{ Control } & $\mathbf{C a C l}_{2}$ & $\mathbf{( 1 . 5 \% )}$ & $\mathbf{C a}\left(\mathbf{N O}_{\mathbf{3}}\right)_{\mathbf{2}}(\mathbf{1 . 5 \%})$ & \multicolumn{2}{c}{$\mathbf{C a O}(\mathbf{1 . 5 \%})$} & \multicolumn{2}{c}{ Means } \\
\cline { 2 - 11 } Cultivars & F.D & F.F & F.D & F.F & F.D & F.F & F.D & F.F & F.D & F.F \\
\hline Early Grand & 31.00 & 4.90 & 18.00 & 7.20 & 18.67 & 6.50 & 18.83 & 5.96 & $21.62 \mathrm{a}$ & $6.14 \mathrm{c}$ \\
Florida King & 26.83 & 5.13 & 14.83 & 7.76 & 21.33 & 6.70 & 22.00 & 6.20 & $21.25 \mathrm{~b}$ & $6.44 \mathrm{~b}$ \\
Tex.A.69 & 22.00 & 5.90 & 13.11 & 8.00 & 16.67 & 6.93 & 19.17 & 6.70 & $17.74 \mathrm{c}$ & $6.75 \mathrm{a}$ \\
\hline Means & $26.61 \mathrm{a}$ & $5.31 \mathrm{~d}$ & $15.33 \mathrm{c}$ & $7.65 \mathrm{a}$ & $20.00 \mathrm{~b}$ & $6.71 \mathrm{~b}$ & $18.88 \mathrm{~b}$ & $6.29 \mathrm{c}$ & \\
\hline
\end{tabular}

Total soluble solids ( $\left.{ }^{0} \mathrm{Brix}\right)$

Data obtained for total soluble solid ( ${ }^{0}$ Brix) for Calcium Sources showed that more TSS 6.31 was recorded in fruits of plants treated with Calcium chloride followed by $(6.20 \&$ $6.03{ }^{0}$ Brix) TSS noted in fruits of plants sprayed with $\mathrm{Ca}\left(\mathrm{NO}_{3}\right)_{2}$ and $\mathrm{CaO}$, respectively while the minimum TSS $(5.82$ ${ }^{0}$ Brix) was recorded in control treatment (Table 2).

Data obtained for peach cultivars indicated that highest (6.26) was recorded in Tex.A.69 cultivar, whereas the lowest 5.99 TSS observed in Early Grand cultivar (Table 2). Taste and flavor of the fruit is due to TSS in combination with acidity. Total soluble solids increase with the application of calcium sources at pre harvest stage [13]. The respiration rate and ripening process reduce with foliar application of $\mathrm{CaCl}_{2}$ converting some acid into sugars [22].

Fruit pH

Table 2. Total soluble solids ( ${ }^{0} \mathrm{Brix}$ ) (TSS) and fruit $\mathrm{pH}$ of three peach cultivars as affected by the three foliar applications of Ca-Sources at $1.5 \%$

\begin{tabular}{|c|c|c|c|c|c|c|c|c|c|c|}
\hline \multirow[b]{2}{*}{ Cultivars } & \multicolumn{2}{|c|}{ Control } & $\mathrm{CaCl}_{2}$ & $(1.5 \%)$ & \multicolumn{2}{|c|}{$\mathrm{Ca}\left(\mathrm{NO}_{3}\right)_{2}(1.5 \%)$} & \multicolumn{2}{|c|}{$\mathrm{CaO}(1.5 \%)$} & \multicolumn{2}{|c|}{ Means } \\
\hline & TSS & $\mathrm{pH}$ & TSS & $\mathrm{pH}$ & TSS & $\mathrm{pH}$ & TSS & $\mathrm{pH}$ & TSS & $\mathrm{pH}$ \\
\hline Early & 5.93 & 3.60 & 6.03 & 3.70 & 6.03 & 3.67 & 5.96 & 3.65 & $5.98 \mathrm{c}$ & $3.65 c$ \\
\hline Grand & & & & & & & & & & \\
\hline $\begin{array}{l}\text { Florida } \\
\text { King }\end{array}$ & 5.63 & 3.59 & 6.20 & 3.69 & 6.16 & 3.67 & 6.06 & 3.64 & $6.01 b$ & $3.64 b$ \\
\hline Tex.A.69 & 5.90 & 3.62 & 6.70 & 3.71 & 6.40 & 3.69 & 6.07 & 3.70 & $6.26 \mathrm{a}$ & $3.68 \mathrm{a}$ \\
\hline Means & $5.82 \mathrm{~d}$ & $3.60 \mathrm{~d}$ & $6.31 \mathrm{a}$ & $3.70 \mathrm{a}$ & $6.20 \mathrm{~b}$ & $3.67 \mathrm{~b}$ & $6.03 c$ & $3.65 \mathrm{c}$ & & \\
\hline LSD & or $\mathrm{Ca}-$ & $(\mathrm{Ca})$ & 6 leve & robabi & $=(\mathrm{TSS})$ & 0.10 & $(\mathrm{pH})$ & & & \\
\hline LSD va & or cult & Cv.) at & $\%$ level & 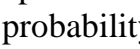 & (TSS) & 0.07 & $(\mathrm{pH})$ & & & \\
\hline
\end{tabular}




\section{Percent acidity}

Data obtained for percent acidity for calcium sources indicated that highest percent acidity $(0.74 \%)$ was observed in fruits of untreated plants whereas the lowest percent acidity $(0.60 \%)$ was observed in fruits of trees treated with $\mathrm{CaCl}_{2}$. The percent acidity of 0.70 and $0.63 \%$ recorded in fruits of plants treated by $\mathrm{CaO}$ and $\mathrm{Ca}\left(\mathrm{NO}_{3}\right)_{2}$ respectively. (Table 3).

Data obtained for peach cultivars revealed that highest $(0.77 \%)$ percent acidity was observed in fruits of Early Grand cultivar, whereas the lowest $(0.70 \%)$ percent acidity was recorded in fruits of Florida King Cultivar. (Table 3).

Calcium chloride dealing with their prospective effect on improving fruit flavor, enhancing fruit quality and reduce percent acidity [19]. Percent acidity is responsible for maintaining the fruit quality that depends on the organic concentration [23]. Acid contents of the fruits may also affect the cellular processes [7]. Foliar application reduced the percent acidity of calcium chloride that negatively affect the rate of respiration, delay in fruit ripening ultimately affecting the acid utilization processes leads to change of acids into sugar contents [21, 22]. Fruit quality was improved by the application of calcium in the pre harvest [24].

\section{Vitamin $C$ content $\left(\mathbf{m g ~} 100 \mathrm{ml}^{-1}\right)$}

Data obtained for Ca-Sources indicated that maximum (7.03 ) Vitamin C Content was observed in fruit plants treated with Calcium chloride followed by (6.20 \& 6.03) Vitamin $\mathrm{C}$ Content recoded in fruit plants sprayed with Calcium nitrate and Calcium oxide respectively. Whereas the minimum (5.47) Vitamin C Content was observed in control treatment (Table 3).

Data obtained for cultivars showed that more (6.3) Vitamin C Content was recorded in fruits of Early Grand cultivar, whereas the less (6.11) Vitamin C Content was observed in fruits of peach cultivar Tex.A.69. (Table 3)

Maintains of fruit quality can be achieved by pre harvest application of Ca-sources as it internally reduced the break down processes [25]. Calcium application may also affect the fruit quality as by changing in total acid contents (Conway, 1987). The research of other scientists also supported our results [18].

Table 3. Percent Acidity (P.A) and vitamin C content (mg $100 \mathrm{ml}^{-1}$ ) (Vit.C) of three peach cultivars as affected by three the foliar applications of Ca-Sources at $1.5 \%$

\begin{tabular}{|c|c|c|c|c|c|c|c|c|c|c|}
\hline \multirow[b]{2}{*}{$\begin{array}{c}\text { Cultivar } \\
\text { s }\end{array}$} & \multicolumn{2}{|c|}{ Control } & $\mathrm{CaCl}_{2}$ & \multirow{2}{*}{$\frac{(1.5 \%)}{\text { Vit C }}$} & \multicolumn{2}{|c|}{$\mathrm{Ca}\left(\mathrm{NO}_{3}\right)_{2}(1.5 \%)$} & \multicolumn{2}{|c|}{$\mathrm{CaO}(1.5 \%)$} & \multicolumn{2}{|c|}{ Means } \\
\hline & P.A & Vit C & P.A & & P.A & Vit C & P.A & Vit C & P.A & $\begin{array}{c}\text { Vit } \\
\mathrm{C}\end{array}$ \\
\hline $\begin{array}{l}\text { Early } \\
\text { Grand }\end{array}$ & 0.85 & 5.74 & 0.70 & 7.14 & 0.72 & 6.47 & 0.81 & 6.07 & $0.77 \mathrm{a}$ & $\begin{array}{l}6.3 \\
5 \mathrm{a}\end{array}$ \\
\hline $\begin{array}{l}\text { Florida } \\
\text { King }\end{array}$ & 0.78 & 5.47 & 0.62 & 6.91 & 0.61 & 6.07 & 0.78 & 5.98 & $0.69 a$ & $\begin{array}{l}6.1 \\
0 b\end{array}$ \\
\hline Tex.A.69 & 0.59 & 5.20 & 0.48 & 7.03 & 0.56 & 6.26 & 0.51 & 6.08 & $0.53 \mathrm{a}$ & $\begin{array}{l}6.1 \\
4 b\end{array}$ \\
\hline Means & $0.74 a$ & $5.47 \mathrm{c}$ & $0.60 \mathrm{~b}$ & $7.03 \mathrm{a}$ & $0.63 b$ & $6.27 \mathrm{~b}$ & $0.70 \mathrm{a}$ & $6.04 b$ & & \\
\hline $\begin{array}{l}\text { LSD va } \\
\text { LSD va }\end{array}$ & $\begin{array}{l}\text { or } \mathrm{Ca}- \\
\text { or cult }\end{array}$ & $\begin{array}{l}\text { e (Ca) } \\
\text { (Cv.) }\end{array}$ & $\begin{array}{l}\text { leve } \\
\text { level }\end{array}$ & obal & $\begin{aligned}= & (\mathrm{P} . \mathrm{A}) \\
& (\mathrm{P} . \mathrm{A})\end{aligned}$ & $\begin{array}{l}0.27 \\
0.29\end{array}$ & $\begin{array}{l}(\text { Vit C) } \\
\text { (Vit C) }\end{array}$ & & & \\
\hline
\end{tabular}




\section{Conclusion and recommendations}

On the basis of results it was concluded that the fruits of peach trees sprayed with $\mathrm{CaCl}_{2}$ at $1.5 \%$ indicated maximum Vitamin $\mathrm{C}$ Content (mg $\left.100 \mathrm{ml}^{-1}\right)$, TSS ( $\left.{ }^{0} \mathrm{Brix}\right)$, fruit $\mathrm{pH}$ and fruit firmness $\left(\mathrm{Kg} . \mathrm{cm}^{-2}\right)$ with lowest percent acidity and number of fruits drops. Cultivar Tex.A.69 showed more TSS $\left({ }^{0}\right.$ Brix), fruit $\mathrm{pH}$, fruit firmness $\left(\mathrm{kg} . \mathrm{cm}^{-2}\right)$ with less number of fruits drops and percent acidity. The present study recommends that foliar application of $\mathrm{CaCl}_{2}$ at $1.5 \%$ could be used to improve the fruit quality attributes of peach cultivars also peach growers should used cultivar "Tex.A.69" for better qualitative attributes of peach fruit for the agro climatic condition of Peshawar.

\section{Authors' contributions}

Conceived and designed the experiments: $M$ Wahab \& Z Ullah, Performed the experiments: $M$ Wahab, S Nayab \& M Ullah, Analyzed the data: M Usman \& K Sohail, Contributed reagents/ materials/ analysis tools: M Sajid \& Z Ullah, Wrote the paper: M Wahab, S Nayab \& M Ullah.

\section{References}

1. Chaudhary MA (1994). Fruit Crops. In: Bashir E \& R Bantel, editors. Horticulture. National Book Foundation. Islamabad. 476-477

2. Agricultural Statistics of Pakistan (2010 2011). Peach production and area. Table 51, page 95. Retrieved from: http://www.pbs.gov.pk/content/agricultur al-statistics-pakistan-2010

3. USDA Nutrient Database (2011). Nutrient data for 09236, Peaches, raw. Retrieved from:http://ndb.nal.usda.gov/ndb/foods/s how $/ 2327$ ?fg $=\&$ man $=\&$ lfacet $=\&$ format $=$ \&count $=\& \max =25 \&$ offset $=\&$ sort $=\& q l o o$ kup=peach.

4. Bassi D \& Monet R (2008). Botany and Taxonomy. In: Lyne D R \& Bassi D, editors. The Peach Botany. Production and Uses: $C A B$ International $U K$. pp. 130

5. Johnson RS (2008). Nutrient and water requirements of peach trees. In: Lyne D R \& D Bassi, editors. The Peach Botany. Production and Uses: $C A B$ International UK. pp. 310-311.

6. Pooviah BW, Glenn GM \& Reddy ASN (1988). Calcium and fruit softening physiology and biochemistry. Horti Revi 10: 107-152.

7. Conway WS (1982). Effect of postharvest calcium treatment on decay of 'Delicious' apples. Plant Disease 66: 402-403.

8. Adaskaveg JE, Ogawa JM \& Feliciano AJ (1992). Comparisons of calciumbased and film-forming materials for control of brown rot of peach caused by Monilinia fructicola. Phytopathol 82: 1158.

9. Biggs AR, El-Kholi MM, El- Neshawy S \& Nickerson R (1997). Effects of calcium salts on growth, polygalacturonase activity and infection of peach fruit by Moniliniafructicola. Plant Disease 81: 399-403.

10. Steel R \& Torri J (1997). Principles and Procedures of Statistics A Biometrical Approach 178.

11. Rasool M \& Khan FU (2012). Effect of calcium, boron and zinc on growth, flowering and bulb (Tulipa gesneriana L.) cv. Apeldoorn. PhD dissertation, Sher-E-Kashmir Uni Of Agri Sci (Srinagar). Retrieved from: http://dspaces.uok.edu.in/jspui//handle/1 $\underline{1065}$.

12. Nijjar GS (1985). Nutrition of Fruit, Published by Mrsusha Rajkumer for Kalyeni publishers New Delhi pp: 10270.

13. Sarrwy SMA, Gadalla EG \& Mostafa EAM (2012). Effect of calcium nitrate and boric acid sprays on fruit set, yield and fruit quality of cv. Amhat Date 
Palm. World J of Agriculture Sci 8: 506515.

14. Ge LL, Tian Q \& Russell SD (2007). Calcium function and distribution during fertilization in angiosperms. Amer J of Botany 94: 1046-1060.

15. Deshpande PB \& DK Salunkhe (1964). Effect of maturity and storage on certain biochemical changes in apricots and peaches. Food Technol 18(18): 85-88.

16. Fallahi E, Conway WS, Hickey KD \& Sams CE (1997). The role of calcium and nitrogen in postharvest quality and disease resistance of apple. Hort Sci 32(5): 831-835.

17. Picchioni GA, Watada EA, Conway WS, Whitaker BD \& Sams CE (1995). Phospholipid, galactolipid and steryl lipid composition of apple fruit cortical tissue following postharvest $\mathrm{CaCl} 2$ infiltration. Phytochem 39 (4): 763-769.

18. El-Alakmy HA (2012). Effect of Calcium Application and Wrapping Treatments on Fruit Quality of Early Grand Peach Trees (Prunus persica L.). J of Appli Sci 8: 3845-3849.

19. Brar SS, Simnani SSA \& Kaundal GS (1997). Effect of pre-harvest sprays of calcium nitrate on the storage life of Shan-I-Punjab peach. J Res Punjab Agric Univ 34(2): 174-180.

20. Guarinoni A, Ferenczi A, Silvera A \& Mori R (2000). Evaluation of postharvest fruit quality of flavor crest peach growing under an integrated production system. IIR Conference Murcia Spain 69: 81.

21. Mahmoud MM (2008). Influence of gamma rays and some pre and post harvest treatments on behavior of some fruits during cold storage. M.Sc. Thesis. Deptt Environmental Sci. Institute of Environmental Studies and Research. Ain Shams Univ of Egypt.

22. Raese JT \& Drake SR (1993). Effect of pre-harvest calcium sprays on apple and pear quality. J of Plant Nutrit 16: 18071918.

23. Kazemi M, Aran M \& Zamani S (2011). Effect of calcium chloride and salicylic acid treatments on quality characteristics of kiwifruit (Actinidia deliciosa cv.) during storage. American J Plant Physiol 6(3): 183-189.

24. Serrano M, Romero DM, Castillo S, Guillén F \& Valero D (2004). Effect of preharvest sprays containing calcium, magnesium and titanium on the quality of peaches and nectarines at harvest and during postharvest storage. J Sci Food \& Agric 84(11): 1270-1276.

25. Bangerth F, Dilley DR \& Dewey DH (1972). Effect of postharvest calcium treatment on internal breakdown and respiration of apple fruits. J Amer Soc Hort Sci 97: 679-682.

26. AOAC (1990). Official Methods of Analysis. The Association of official Analytical Chemist, $17^{\text {th }}$ Edn. Chap17. 